\title{
Future of energy labs under further scrutiny
}

Washington. The US Department of Energy has started yet another round of reviews of its sprawling network of research laboratories, deferring any action to streamline them until after November's presidential and congressional elections.

Announcing the reviews last week, Charles Curtis, the deputy energy secretary, ruled out the closure or consolidation of any of the larger laboratories. He added that privatization would only be considered for seven small ones, each with annual budgets of less than $\$ 50$ million.

Republicans in Congress say that a preliminary plan for the laboratories released by the Department of Energy falls considerably short of the strategic plan that the department promised to deliver this year. But the Congress will be in session for only one more month September - this year, and will not revive the issue of laboratory reform until 1997.

Curtis announced four new reviews of the laboratory network, which employs more than 50,000 people in centres ranging from the Los Alamos nuclear weapons laboratory in New Mexico to the newly opened Thomas Jefferson accelerator laboratory in Virginia. The network houses most large physics experiments in the United States, has unmatched expertise in nuclear weapons design, supercomputer use and materials science, and significant activity in most other scientific disciplines.

The first review is to be completed by the energy department's Laboratory Operations Board by 1 November. It will assess whether the department's programme managers are making the right choices between the laboratories and other options, such as universities, in deciding where to do research.

In a second review, next year, the board

\section{Standards buildings fight for funds}

Washington. Prospects are fading for badly needed renovations and new facilities at the US National Institute of Standards and Technology (NIST), formerly known as the National Bureau of Standards. The agency finds itself in a losing battle with Congress over the way it handled its construction fund's last year.

A \$540-million renovation plan for NIST's two main sites, at Gaithersburg, Maryland, and Boulder, Colorado, is already being revised. The plan sank deeper into trouble last week, when Senate appropriations committee members joined their counterparts in the House of Representatives in rejecting an adminstration request for $\$ 105$ million towards the plan next year.

The agency started work on 29 July on a \$57-million chemistry laboratory at Gaithersburg (pictured). This project had become NIST's top priority because of deterioration in the existing laboratory, aggravated by asbestos problems. The work is likely to be completed on schedule in 1998 .

But more ambitious plans for state-ofthe-art metrology laboratories on both sites, along with the renovation of facilities built between 30 and 45 years ago, seem unlikely to proceed, after the Senate appropriations committee offered NIST \$15 million for construction next year "for maintenance and safety".

Senate appropriators also allocated $\$ 60$ million for the Advanced Technology
Programme (ATP), which is strongly favoured by President Bill Clinton. The House had offered $\$ 110$ million, against $\$ 345$ million requested by Clinton. But the Senate rejected a House provision that would have ejected medium-sized and large companies from the programme.

The standards-related work of NIST has strong bipartisan support, and continues to attract full funding from the Congress. But the removal of the conso struction funds, which would have financed an overall plan forged under the Republican administration of President George Bush, indicates that the agency is suffering in Congress for its association with the ATP.

Connie Morella

(Republican, Maryland), chair of the technology subcommittee of the Science Committee in the House of Representatives, who has NIST's Gaithersburg site in her district, says that she will continue to fight for the new laboratories.

Morella says that support for NIST's core programme remains solid, and construction funds could be restored if appropriators and the agency can settle an arcane argument about how the agency classified some money that Congress sought to cut from its budget last year. "I'm hoping we can smooth things over," Morella said before last week's Senate action, which makes the hope look forlorn, this year at least. C. M. will examine the possible privatization of the seven smallest single-purpose laboratories. Last week one such laboratory - the National Institute for Petroleum and Energy Research at Bartlesville, Oklahoma - was singled out for privatization in 1998.

The third review will deal with the strategic plans of the nine large, multi-purpose laboratories. A final review, to be conducted by the outside members of the operations board (which mixes senior civil servants with outside experts), will assess how peer review is applied to research programmes.

Curtis was asked why the Clinton administration was ending four years of alleged effort to reform the laboratories with the promise of yet more reviews. He said that the review process would survive any change of administration, as it drew on the most senior civil servants in the department and outside expertise from individuals with various political views. The board's vice-chairman is John McTague of Ford, a former adviser to President Ronald Reagan.

"We've made a concerted effort to make sure that this work will extend from one administration to the next," Curtis said. He added that the current review process and the preliminary plan were different from previous efforts, because they "follow the money" in the laboratory network. He said that "the most important review" was the first one, which would be ready in time to influence the first budget proposal of the next administration, due next February.

Early in the life of this administration, Hazel O'Leary, the energy secretary, asked Bob Galvin, an executive with Motorola, to head a task force to review the laboratories. In February 1995, Galvin issued a scathing report that called for radical changes in the governing structure of the laboratories; efficiency improvements to cut costs by onethird; and the ending of independent nuclear weapons design at the Lawrence Livermore laboratory in California (see Nature 373, 463; 1995).

Galvin's proposed changes attracted early interest from Republicans in Congress, who sought to begin reform at the top by abolishing the Department of Energy. Some congressmen called for a "closure commission" to shrink the laboratory network. But senior Republicans such as Senator Pete Domenici (New Mexico), chair of the Budget Committee and energy appropriations sub-committee in the Senate, succeeded in defending the department and its laboratories.

According to congressional staff, however, the issue of abolishing the department and reforming the laboratories will be revived next year if Republicans retain control of Congress. One staff member doubted that Domenici will fight as hard to defend the laboratories once he achieves his goal of re-election in November. Colin Macilwain 